\title{
Study on the Communist Values Thoughts and Contemporary Value of Marx and Engels
}

\author{
Shihua Jiang, Zhiguo Bao \\ Publicity Department of Party Committee, Sichuan University of Arts and Science, Dazhou, China \\ Email: 41359942@qq.com
}

How to cite this paper: Jiang, S. H., \& Bao, Z. G. (2020). Study on the Communist Values Thoughts and Contemporary Value of Marx and Engels. Open Journal of Social Sciences, 8, 111-117.

https://doi.org/10.4236/jss.2020.88009

Received: July 16, 2020

Accepted: August 16, 2020

Published: August 19, 2020

Copyright $\odot 2020$ by author(s) and Scientific Research Publishing Inc. This work is licensed under the Creative Commons Attribution International License (CC BY 4.0).

http://creativecommons.org/licenses/by/4.0/

\begin{abstract}
The Communist Manifesto is a great symbol of the birth of scientific socialism. Marx and Engels comprehensively and profoundly discussed the value subject, value orientation, realization path and ultimate goal of the Communist values in their work and others, which provided a strong scientific theoretical basis and practical guiding value for the liberation of the proletariat and the development of the communist cause. This article will elaborate the rich connotation of Marx and Engels communist values thought from the above four aspects and the guiding significance to the reality.
\end{abstract}

\section{Keywords}

Marx, Engels, Communist Values

\section{Introduction}

Marx and Engels founded scientific socialism on the basis of historical materialism. As the symbol of the birth of Marxism, the Communist Manifesto (hereinafter referred to as the Manifesto) elaborated the values of the Communist Party from many angles. Marx and Engels deeply discussed the values of the Communist Party of value subject, value orientation, realization and the ultimate goal, from the perspective of the forming process of Marx and Engels political party values ideas, produced in capitalist socialization production period, reflected and represented the fundamental interests of the proletariat, which provided scientific theoretical guidance and action guide for the proletariat revolution and liberation, and showed a strong vitality and practical guidance value in the contemporary.

\section{The Value Subject of the Communist Values of Marx and Engels}

The subject of value is the actual undertaker of value and the basis for the for- 
mation of value relations. The establishment of the value subject of The Communist Party of Marx and Engels is based on the scientific analysis of the mission and goal of the proletariat in the social, and historical development of Marxist classical writers standing at the height of social and historical development, and analyzing the advanced class representing the direction of social development. Marxism is a theory of the emancipation of the proletariat and of all mankind. The proletariat has always been the subject that Marx and Engels paid attention to. Because of its historical mission and its own advanced nature, the proletariat has become the value subject that practices the values of the Communist Party. The proletariat emerged with the industrial revolution and the establishment of the capitalist system. Its survival and development are closely connected with the machine industry. "While the rest of the classes have fallen and perished with the development of the great industry, the proletariat is the product of the great industry itself" (Marx \& Engels, 2018: p. 38). This characteristic determines that the proletariat is the representative of the advanced productive forces, the most advanced and promising class. The proletariat is also the most revolutionary class. In the capitalist society, the proletariat is exploited and oppressed by the bourgeoisie, suffered and oppressed seriously who is alienated from his product of labor, his activity of labor, and his kind essence. It has become the historical mission of the proletariat to bury capitalism and build socialism. "The proletariat, the lowest stratum of modern society, can't raise its head and chest without blowing up the entire upper stratum constitutes of the official society" (Marx \& Engels, 2018: p. 39). The proletariat is also the most organized and disciplined class at the same time, under the condition of socialized mass production, and with the development of transportation, the proletarian union is more and more closely, the proletarian struggle from spontaneous to conscious, from initial individual behavior, group behavior to union, to the class struggle. "The proletarians organized themselves into classes, and eventually into political parties, were continually undermined by the self-competition of the workers. But it always regenerated and grew stronger and stronger, and powerful every time" (Marx \& Engels, 2018: p. 37). Marx and Engels examined the main forces driving social progress and development from the perspective of the whole world and all mankind, broke through the limitation of the thinking of vested interests, and highlighted the proletarian consciousness of self-criticism, self-reflection and self-revolution. Throughout the development of human society and history, only those who are walking in the forefront of social development, on behalf of the development direction of advanced productivity class finally can become the subject of political values, become one of the most outstanding representatives of time value subject; however, those who on behalf of the special interests of the vested interests will eventually be swept into the dust of history.

The value subject status of the proletariat is represented and realized by the proletarian political party. The proletariat "begins as a single worker, then as a 
worker in a factory, then as a worker in a department of Labour somewhere, and fights against the single bourgeois who exploits them directly" (Marx \& Engels, 2018: p. 35). The workers' struggle at this stage consisted only of sporadic struggles in the form of destroying machinery, burning down factories, etc. Later, it began to assemble on a large scale and developed into a party organization in the struggle with the bourgeoisie against feudal autocracy, then, which made unremitting efforts for the Communist movement and promoted the continuous development of social history in theory and practice. In terms of the aims of the struggle, "the immediate aims of the Communists are the same as those of all other proletarian political parties: to form the proletariat into a class, to overthrow the rule of the bourgeoisie, and for the proletariat to seize power" (Marx \& Engels, 2018: p. 41). In terms of means of struggle, the proletarian political party overcomes the limitations of other classes and political parties, implements the worker-peasant and the proletarian alliance, breaks the boundary between regions and countries, and regards the liberation of all mankind and the realization of communism as the ultimate goal of struggle. These classical treatises of Marx and Engels fully embody that the proletariat must realize its value subject status through its own political party.

\section{The Value Orientation of the Communist Values of Marx and Engels}

The value orientation is the basic value standpoint, basic value attitude and basic values that the value subject holds in facing and dealing with various contradictions, social relations and interest conflicts in the process of social practice. "In class society, the values of any political party have their main orientation, that is, the value orientation and evaluation criteria of who the party exists for, who is in power for, and whose interests it takes as its value orientation" (Zhu \& Wang, 2016: pp. 65-66). Marx critically inherited Feuerbach subjective materialism and dialectics of Hegel's idealism, on the basis of achieved from idealism to materialism, the transition from revolutionary democratic socialism to communism, is always the real people, the people in a certain social relations as the starting point of historical materialism, for their investigation. "The first premise of all human history is undoubtedly the existence of a living individual. So the first thing that needs to be confirmed is the physical organization of these individuals and the resulting relationships of individuals to other nature" (Marx \& Engels, 1999: p. 5). The people are the driving force for historical development and the creators of material and spiritual wealth of society. Upholding the position of the people and their creation of history is the basic position of Marxist historical materialism.

"What is the relation of the Communist Party to the proletariat as a whole? The Communists are not a special party in opposition to other workers' parties. They have no interests distinct from those of the proletariat as a whole" (Marx \& Engels, 2018: p. 41). The Communist Party always represented the fundamental interests of the people, came from the people, was a few outstanding representa- 
tives of the people, and always seeks the interests of the vast majority of people. Marx and Engels clearly pointed out in the Manifesto that "all movements in the past were those of a minority, or in the interests of a minority. The proletarian movement was an independent movement for the benefit of the great majority" (Marx \& Engels, 2018: p. 39). As the proletarian loyal interests of the representative of the Communist is not different from the interests of the proletariat, in the revolutionary struggle of different nationalities in the world, the Communists advocate and adhere to the common interests of the entire proletariat, break barriers and boundaries between nationalities. In every stage of the struggle between the proletariat and the bourgeoisie, the Communist Party always represents the direction of society and always centers on the fundamental interests of the masses. Marxist political party is the class basis of the proletariat; the vast majority of the population always represent the reasonable demand of the proletariat, to ensure that party the correct value orientation. Therefore, the value orientation of The Communist Values of Marx and Engels has always been based on the core and fundamental position of the people, who are the source of the strength of the Communist Party and the important reliance of the Communist class revolution.

\section{The Realization Path of the Communist Values of Marx and Engels}

The weapon of criticism cannot replace the weapon of criticism; the communist values can only become reality in the social revolution. After the establishment of the capitalist system, it played a positive and important role in promoting the historical development of human society. During its reign of less than one hundred years, it created more material wealth than all previous generations. However, the exploitation of workers and the oppression of the proletariat also existed along with the emergence of the capitalist system. The bourgeoisie relies on various means to extract the surplus value created by the workers, but the proletariat suffers the most severe exploitation and oppression in the capitalist society. The proletariat has nothing in the capitalist society. They have to sell their labor force to survive and live a life of hunger, cold and poverty. "The workman had become a mere adjunct to the machine, and was required to perform operations extremely simple and monotonous, and extremely easy to learn. Therefore, the cost to the worker, was almost limited to the means of subsistence necessary to sustain and continue their offspring" (Marx \& Engels, 2018: p. 34). In the capitalist society, barely enough to maintain the life of workers' basic need information to less than fully safeguard, sometimes with the development of science and technology, capital and technology constitute a significant change occurred, and with the contradiction between the socialization of production and the material private possession, often leads to cyclical economic crisis, workers facing unemployment, life will also have no security.

The workers not only suffer from exploitation and oppression of the person of the bourgeoisie, also suffered from political oppression. The bourgeoisie domin- 
ance in the economy, began to seek dominance in politics, and through the legislation, jurisdiction and the propaganda consolidating the political position of this class. The proletariat had no right to vote, no right to participate in political affairs and no political power. In terms of ideology and culture, the bourgeoisie takes advantage of various propaganda positions to advocate bourgeois ideology and exercise ideological paralysis and control over the proletariat. In terms of education, because the bourgeoisie has the right to education, they worry that the working class, after being educated, will have the potential threat of getting rid of the ideological control of the bourgeoisie, and the proletariat will have difficulty in enjoying a fair and just education. The general root of the proletariat's poverty, exploitation and oppression is capitalist private ownership. On the premise that there is no political position to express reasonable interest demands, private ownership can only be eliminated through class struggle. Only by uniting the proletariat of the world can the complete emancipation of all mankind be achieved. Overthrowing the bourgeois rule and establishing the proletarian political power is the only way for the proletariat to realize its own liberation and the emancipation of all mankind. Only in this way can it better liberate and develop the productive forces. Therefore, burying capitalism and establishing the proletarian regime became the way to realize Marxist Communist values.

\section{The Value Goal of the Communist Values of Marx and Engels}

The value pursuit of a political party is the goal of its long-term development, a profound understanding of its historical mission, and the fundamental reason for its establishment. In human society development history, has experienced the different dynasty era of change, social change, in this process, the ruler of past personal or represented by a special class of tend to sit enjoy privileges, grab the special interests for the purpose, aiming at how to consolidate its ruling regime, seldom considering how to promote the development of the society, let alone make the final judgment on the development of human society. It was only when the proletariat had established its political party that it took a great leap of faith to set forth the long-term goals of social development. The value goal of Marxist political party is the dialectical unity of short-term value goal and long-term value goal, and the dialectical unity of proletarian value goal and the value goal of the whole human society. Unlike bourgeois parties, the Communist Party does not hide its pursuit of values, but publicly declares its views and goals.

The ultimate value goal of the Communist Party is to realize communism. Communism "was a substitute for the bourgeois society in which classes and class antagonisms existed, and would be a union in which the free development of every man was a condition for the free development of all men" (Marx \& Engels, 2018: p. 51). Communism "is the real solution to the contradiction between man and nature, between man and man, the real solution to the struggle between existence and essence, objectification and self-confirmation, freedom and 
necessity, individual and class" (Marx \& Engels, 2009: p. 186). Marx and Engels also made comprehensive and systematic assumptions about the communist social system. In terms of ownership, communism meant the abolition of private ownership. In Labour, the social division of Labour and the opposition between mental and physical Labour will disappear. In terms of distribution of social products, communism will be a great enrichment of social material wealth, and labor products will be distributed according to needs. In terms of social relations, class and state will also disappear. The industrial civilization, urban civilization and spiritual civilization of mankind will be highly developed. There will be mutual harmony between man and nature, between man and man, and between man and society.

\section{The Contemporary Values of the Communist Values of Marx and Engels}

The Communist Values Thoughts of Marx and Engels has been continuously enriched and developed since its founding. It has formed a relatively rich and profound ideological system, which has been successively inherited, innovated and developed by Lenin, Stalin, Mao Zedong, Deng Xiaoping, Jiang Zemin, Hu Jintao and Xi Jinping, etc. Especially represented by Xi Jinping, a new generation of the Communist Party of China people standing in the new era of global development of the cause of the party and the country, combined with the era development and construction of the Communist Party of the Communist Party of China own values, high profile and would be concentrated expression for "Loyalty and honesty, Fairness and decency, Seeking truth from facts, Honesty and integrity" etc. The values of the Communist Party in the new era are embodied such as in the party members' political ideals, behaviors and attitudes, behaving and handling affairs, working and living style.

"Loyalty and honesty" is the most basic requirement of every party member, a touchstone to test the purity of party spirit and political consciousness of party officials, and also a solemn promise that every party member must make when taking an oath to join the Party. "Fairness and decency" is the basic principle for handling inner-party relations, the internal requirement for creating clean and refreshing comity and building a sound political environment, and an important criterion for training and selecting cadres. "Seeking truth from facts" is an important methodology for understanding, observing and transforming the world, and is also the essence of Marxist thought and the basic principle by which every party members and cadres start business and serve the people. "Honesty and integrity" is an important guide for party members and cadres to establish a correct view of rights and interests, an important part of preventing and combating corruption and promoting integrity, and an important method for the party to keep in close contact with the masses.

Every word of new era Communist Party values has rich connotation, which is a profound summary of the party's construction experience and party members 
and cadres of the highest code of conduct, the core of composition to strengthen the construction of the party's political ecological culture in new era, the important ideological source for Chinese Communists to strengthen their ideals and beliefs and conduct party spirit education, and the basic norms and requirements for the construction of intraparty political culture and the serious intraparty political life.

\section{Conflicts of Interest}

The authors declare no conflicts of interest regarding the publication of this paper.

\section{References}

Marx, \& Engels (1999). Selected Readings of Marxist Classics (p. 5). Beijing: People's Publishing House.

Marx, \& Engels (2009). Collected Works of Marx and Engels (Vol. 1, p. 186). Beijing: People's Publishing House.

Marx, \& Engels (2018). Manifesto Communist (pp. 38-51). Beijing: People’s Publishing House.

Zhu, Y. J., \& Wang, X. (2016). The Logical Generation of Marxist Party Values-Based on the Investigation of the Manifesto of the Communist Party. Theory Guide, No. 4, 65-66. 